\title{
COFFEE SEEDLINGS IN DIFFERENT SUBSTRATES AND PROTECTED ENVIRONMENTS
}

\section{ARTHUR P. DA SILVA ${ }^{1}$, EDILSON COSTA ${ }^{2}$, TIAGO L. DO ESPÍRITO SANTO ${ }^{3}$, LUAN E. DA SILVA ${ }^{4}$, ROBERTA F. MARTINS ${ }^{5}$}

\begin{abstract}
The production of high-quality seedlings is a critical factor for successful implementation of a determined crop in the field. In order to evaluate the production of coffee seedlings, experiments were conducted with different substrates and in different protected environments. Treatments consisted of evaluation of the following substrates: $50 \%$ cattle manure + $50 \%$ commercial substrate, $50 \%$ cattle manure $+50 \%$ vermiculite, $50 \%$ commercial substrate + $50 \%$ vermiculite, $1 / 3$ cattle manure $+1 / 3$ commercial substrate $+1 / 3$ vermiculite, $50 \%$ cattle manure $+50 \%$ sand, $1 / 3$ sand $+1 / 3$ cattle manure $+1 / 3$ commercial substrate and $50 \%$ commercial substrate $+50 \%$ sand. These substrates were tested in different protected environments: agricultural greenhouse, mesh screen with 50\% shading, aluminized screen with 50\% shading, black screen with $30 \%$ shading, black screen with $70 \%$ shading, nursery with a buriti straw roof and full sunlight. In each environment, the experiments were conducted in a completely randomized design with five replicates of four plants each followed by joint analysis. The substrates containing $50 \%$ cattle manure associated with vermiculite or the commercial substrate may be indicated for production of coffee seedlings. Screened environments with 30, 50 and $70 \%$ shading resulted in the highest quality seedlings.
\end{abstract}

KEYWORDS: Coffee arabica, cattle manure, vermiculite, commercial substrate, sand.

\section{MUDAS DE CAFÉ EM DIFERENTES SUBSTRATOS E AMBIENTES PROTEGIDOS}

RESUMO: A formação de mudas de qualidade é fator primordial para o sucesso da implantação da cultura a campo. Com o objetivo de avaliar a formação de mudas de cafeeiro, realizaram-se experimentos com diferentes substratos e ambientes protegidos. Os tratamentos consistiram na avaliação dos seguintes substratos: $50 \%$ esterco bovino $+50 \%$ substrato comercial; $50 \%$ esterco bovino $+50 \%$ vermiculita; $50 \%$ substrato comercial $+50 \%$ vermiculita; $1 / 3$ esterco bovino $+1 / 3$ substrato comercial $+1 / 3$ de vermiculita; $50 \%$ esterco bovino $+50 \%$ areia; $1 / 3$ areia $+1 / 3$ esterco bovino $+1 / 3$ substrato comercial, e $50 \%$ substrato comercial $+50 \%$ areia. Estes substratos foram testados no interior de diferentes ambientes protegidos: estufa agrícola; telado de cor preta de 50\%; telado de cor aluminizada de $50 \%$; telado de cor preta de $30 \%$; telado de cor preta de $70 \%$ de sombreamento; viveiro com palha de buriti e pleno sol. Em cada ambiente, os experimentos foram conduzidos em delineamento inteiramente casualizado, com cinco repetições de quatro plantas cada e posterior análise conjunta. Os substratos contendo $50 \%$ de esterco bovino associados à vermiculita ou ao substrato comercial são indicados para a formação de mudas de cafeeiro. Os ambientes telados com telas de $30 ; 50$ e $70 \%$ de sombreamento propiciam a formação de mudas mais vigorosas.

PALAVRAS-CHAVE: Coffee arabica, esterco bovino, vermiculita, substrato comercial, areia.

\footnotetext{
${ }^{1}$ UEMS, Aquidauana-MS, arthur_silva15@hotmail.com.

${ }^{2}$ Professor Adjunto da UEMS/Cassilândia - MS, mestrine@uems.br.

${ }^{3}$ Bolsista PIBIC/CNPQ, Aquidauana-MS, tiagropec@hotmail.com.

${ }^{4}$ UEMS, Aquidauana-MS, luan.2222@hotmail.com.

${ }^{5}$ Mestre em Agronomia, Aquidauana-MS, Bolsista CAPES, beta.joao@terra.com.br.

Recebido pelo Conselho Editorial em: 16-8-2012

Aprovado pelo Conselho Editorial em: 13-2-2012
} 


\section{INTRODUCTION}

Coffee is one of the main agricultural products produced worldwide in different climate and soil types, subject to different planting methods. Coffee production has always been a very common practice in Brazil, which has been the largest producer for more than a century, accounting for approximately $30 \%$ of world production. This activity plays an important economic and social role by generating jobs and increasing foreign exchange.

All production steps are necessary for achieving success in agriculture, initiating with the production of seedlings with vigor and quality. In the seedling stage the plants require adequate agricultural substrates and protection against the climate, as well as appropriate management of irrigation, nutrition and pest control. Studies of substrates for the formation of coffee seedlings have been performed by ANDRADE NETO et al. (1999), CUNHA et al. (2002); FAVARIN et al. (2008), MARANA et al. (2008), DIAS \& MELO (2009) and DIAS et al. (2009), while studies with protected environments were conducted by CARELLI et al. (1999), BRAUN et al. (2007) and TATAGIBA et al. (2010).

In the study with an artificial substrate (BioPlantcafé) supplemented with cattle manure, earthworm castings, and turkey litter, in proportions of 0, 20, 40, 60, 80 and 100\%, DIAS et al. (2009) found that the addition of $80 \%$ earthworm castings or the castings alone $(100 \%)$ increased the leaf area of coffee seedlings, and consequently provided greater dry mass accumulation in the shoots (DIAS et al., 2009). The use of cattle manure at concentrations exceeding $30 \%$ and turkey litter did not alter or reduce the vegetative characteristics of seedlings (height, stem diameter, number of leaves and leaf area) and decreased the accumulation of dry matter.

COSTA et al. (2010a) report several studies comparing environments protected for seedling production, where types of roofing material, percentages of shading by screens and environment cooling infer different responses to plant development. COSTA et al. (2009) found that black screen (50\% shading) produced greater passion fruit seedlings than greenhouse. MENDONÇA et al. (2005) obtained better papaya 'Formosa' seedlings under controlled conditions in greenhouse than black screen of $50 \%$ of shading.

Shading levels of 0, 30 and 50\% did not influence the height and diameter of Eriotheca pubescens seedlings (CARRIJO et al., 2009), but in Turkish seedlings (Parkinsonia aculeata) level of $0 \%$ shading promoted better seedlings than the black screen of $75 \%$ of shading (FARIAS JUNIOR et al. 2007). MEDINA et al. (2002) found better photosynthetic performance of citrus seedlings of 'Pera' orange (Citrussinensis Osbeck) and Rangpur lime (Citruslimonia Osbeck) under greenhouse using thermal reflector screen of $50 \%$ shading under the polyethylene film in comparison with the greenhouse without the screen.

Following introduction of the protected environment, they emerged another element associated with the substrates, recipients and fertilizers, acting jointly in order to increase the quality of the future plant. Protection of the plant, both in the seedling and production stages, against adverse weather permits its growth during any period of the year and in several regions of Brazil.

Because the coffee plant has a C3 metabolism it easily adapts to shaded environments. However, TATAGIBA et al. (2010) reported that there are a few experiments on the formation of the seedlings in environments of full sunlight. In the evaluation of seedlings at different shading levels (22, 50 and 88\%) and full sunlight, the authors found that the best vegetative growth was at 22 and 50\% shading, with plants presenting more total dry matter than those grown in full sunlight and at $88 \%$. These authors also noted that there was an increase in height and leaf area with increased shading, whereas the stem diameter was reduced in the environment with $88 \%$ shading.

Due to the importance of coffee production in Brazil, the objective of the present study was to evaluate different methods for the formation of coffee seedlings using different substrates without the addition of chemical fertilizers, and different environments in the region of Aquidauana-MS, Brazil. 


\section{MATERIAL AND METHODS}

Experiments on the formation of coffee seedlings in different substrates and environments were conducted from November $22^{\text {nd }}, 2010$ to March 22 ${ }^{\text {nd }}, 2011$ (120 days), at the Universidade Estadual de Mato Grosso do Sul, Aquidauana Campus, with an elevation of $174 \mathrm{~m}, 55^{\circ} 40^{\prime} \mathrm{W}$ longitude and $20^{\circ} 27^{\prime} \mathrm{S}$ latitude. The climate of the region is Aw according to the Köppen classification, defined as humid tropical with average annual temperature of 27 to $29^{\circ} \mathrm{C}$.

The recipients used for producing the seedling were black polyethylene bags with dimensions of $10 \times 15 \mathrm{~cm}(0.48 \mathrm{~L})$, filled with the following substrates: (S1) 50\% cattle manure + 50\% commercial substrate, (S2) 50\% cattle manure + 50\% vermiculite, (S3) 50\% commercial substrate + $50 \%$ vermiculite, (S4) $1 / 3$ cattle manure $+1 / 3$ commercial substrate $+1 / 3$ vermiculite, (S5) $50 \%$ cattle manure $+50 \%$ sand, (S6) $1 / 3$ sand $+1 / 3$ manure $+1 / 3$ commercial substrate and (S7) $50 \%$ commercial substrate $+50 \%$ sand (Table 1 ). Medium texture vermiculite was used, as well as manure, agricultural residue which is abundant in the region of Aquidauana, MS. The commercial substrate use was Vida Verde ${ }^{\circledR}$.

The substrates were tested in the following environments: (A1) agricultural greenhouse made of galvanized steel $(18.00 \mathrm{~m} \times 6.40 \mathrm{~m} \times 4.0 \mathrm{~m})$, covered with a low density polyethylene (LDPE) film and thermo-reflective screen with 50\% shading on the film, as well as a black screen for $50 \%$ shading on the sides and front, (A2) nursery constructed of galvanized steel (18.00 m x $6.40 \mathrm{~m} \times 3.5$ $\mathrm{m})$ with black screen for $50 \%$ shading, closed at $45^{\circ}$, (A3) nursery constructed of galvanized steel $(18.00 \mathrm{~m} \times 6.40 \mathrm{~m} \times 3.5 \mathrm{~m})$ with an aluminum color thermo reflective screen providing $50 \%$ shading, closed at $45^{\circ}$, (A4) nursery constructed of wood $(5.20 \mathrm{~m} \times 5.20 \mathrm{~m} \times 2.0 \mathrm{~m})$ with black screen to provide $30 \%$ shading at the roof and lateral openings, (A5) nursery constructed of wood $(5.20 \mathrm{~m} \times 5.20 \mathrm{~m} \times 2.0 \mathrm{~m})$ with a black screen to provide $70 \%$ shading at the roof and lateral openings, (A6) nursery constructed of wood $(5.0 \mathrm{~m} \times 1.20 \mathrm{~m} \times 1.80 \mathrm{~m})$ covered with buriti palm straw (Mauritia flexuosa) and open on the sides, (A7) nursery in full sun sunlight with wooden benches. Galvanized steel environments contained bench tops with heights of $1.10 \mathrm{~m}$. In the other environments the bench tops were constructed of wood and were at $0.80 \mathrm{~m}$.

TABLE 1. Chemical analysis of organic materials in the substrates used in experiments of coffee seedlings. Aquidauana - MS, Brazil, 2010.

\begin{tabular}{|c|c|c|c|c|c|c|c|c|}
\hline & \multicolumn{8}{|c|}{--------------------------------------------------- $\mathrm{g} \mathrm{kg}^{-1}$} \\
\hline & $\mathrm{N}$ & $\mathrm{P}$ & $\mathrm{K}$ & $\mathrm{Ca}$ & $\mathrm{Mg}$ & S & $\mathrm{C}$ & $\mathrm{MO}$ \\
\hline CM & 9.30 & 1.82 & 1.00 & 4.95 & 0.90 & 1.07 & 112.00 & 192.00 \\
\hline \multirow[t]{3}{*}{ CS } & 4.20 & 0.77 & 2.00 & 5.60 & 6.20 & 2.46 & 217.00 & 373.00 \\
\hline & - & - & - & - & - & $\mathrm{mg} \mathrm{kg}^{-1}$ & & -- \\
\hline & $\mathrm{pH}$ & M & $\mathrm{C} / \mathrm{N}$ & $\mathrm{Cu}$ & Zn & $\mathrm{Fe}$ & $\mathrm{Mn}$ & B \\
\hline CM & 7.10 & 14.12 & 12.04 & 14.00 & 103.00 & 6000.00 & 239.50 & 12.19 \\
\hline $\mathrm{CS}$ & 5.10 & 15.76 & 51.67 & 31.00 & 47.00 & 10300.00 & 129.00 & 22.31 \\
\hline
\end{tabular}

* Solanalise soil analysis laboratory, Dourados-MS, Brazil. $\mathrm{OM}=$ organic material; $\mathrm{M}=$ moisture (\%) at $65^{\circ} \mathrm{C}$; $\mathrm{CM}=$ cattle manure; $\mathrm{CF}=$ cassava foliage; $\mathrm{CS}=$ commercial substrate.

For evaluation of the substrates within the environments a completely randomized design was used with five replicates and four plants per replicate. First the data was subjected to analysis of variance for the individual substrates (for each growth environment), followed by evaluation of the mean squares of the residues (BANZATTO \& KRONKA, 2006) and joint analysis of the environments. The statistical program Sisvar 5.3 (FERREIRA, 2010) was utilized, where the averages were compared by the Tukey-test at 5\% probability.

The coffee seeds were purchased from commercial grower in Ivinhema-MS, Brazil, and were collected from healthy and vigorous plants. Planting was performed at the depth between 1 and 3 $\mathrm{cm}$ on November $22^{\text {nd }}$, 2010 with two seeds per container, and thinning was performed when the plants had two true leaves. Irrigation was performed manually with a watering can twice a day in the morning and afternoon when necessary until saturation of the substrate, observed by the 
initiation of water flow on the surface. Cattle manure was composted for 30 days, and was wetted and turned over until obtaining a lower temperature and change in color.

Emergence occurred on December $17^{\text {th }}\left(25\right.$ DAS). From December $17^{\text {th }}, 2010$ to January $6^{\text {th }}$, 2011 data was collected on seedling emergence, and the emergence speed index (ESI), emergence percentage (EP), average emergence time (AET) and average emergence speed (AES) were calculated. Counting was as follows: as soon as one of the treatments stabilized, i.e., the number of emerged plants is repeated in the last three samples, the experiment was stopped. Results of emergence were transformed into the root of $(x+0.5)$.

Plant heights (PH) at 90 and 120 DAS and the number of leaves (NL) at 120 DAS were measured. At 120 DAS the stem diameter (SD), shoot dry matter (SDM), root dry matter (RDM) and percentage of survival (POS) were analyzed. Drying of the collected plant matter was performed in a forced air oven at $65^{\circ} \mathrm{C}$ for 72 hours. The SDM and RDM were summed to obtain the total dry matter (TDM).

Temperatures were evaluated daily at $09 \mathrm{~h} 00,12 \mathrm{~h} 00$ and $15 \mathrm{~h} 00$ in each growth environment throughout the experiment period by thermo-hygrometer. Subsequently, the relative humidity was determined with the aid of the software Psychrometric Function Demo (Table 2). Dry and wet bulb temperatures were measured with the analog thermo-hygrometers at the center of the bench top, 1.0 $\mathrm{m}$ above the ground for each environment.

The relative humidity was not obtained directly from thermo-hygrometer, because they could introduce errors. This was obtained from dry and wet bulb temperatures, collected from the thermohygrometer analog, combined with local altitude, and performs calculations with software, for better accuracy.

In each cultivation environment a thermo-hygrometer was installed. Temperatures collections were made in less than 5 minutes by two people, where one person performed the reading and another took notes on the worksheet. The equipment was put in a place that did not receive direct radiation; however there was no guarantee the air speed of $2.5 \mathrm{~m} / \mathrm{s}$.

TABLE 2. Average Temperature $\left({ }^{\circ} \mathrm{C}\right)$ and Relative Humidity (\%) at $09 \mathrm{H}, 12 \mathrm{H}$ and $15 \mathrm{H}$ in the growing and external environments. Aquidauana - MS, Brazil 2010.

\begin{tabular}{lrrrrrr}
\hline & \multicolumn{3}{c}{ DBT } & \multicolumn{3}{c}{ RH } \\
\hline & 09 Hours & 12 Hours & 15 Hours & 09 Hours & 12 Hours & 15 Hours \\
Greenhouse & 28.0 & 31.7 & 32.1 & 75.4 & 63.6 & 62.2 \\
Black screen 50\% & 27.8 & 32.1 & 32.5 & 76.7 & 62.7 & 61.9 \\
Aluminized screen 50\% & 27.9 & 32.1 & 32.5 & 80.7 & 66.0 & 65.7 \\
Black screen 30\% & 28.9 & 32.4 & 32.4 & 76.5 & 62.4 & 61.8 \\
Black screen 70\% & 28.5 & 32.1 & 32.7 & 76.3 & 62.2 & 60.4 \\
Straw & 28.2 & 31.9 & 32.0 & 76.2 & 63.0 & 62.6 \\
Full sunlight & 27.9 & 31.8 & 32.2 & 80.7 & 67.0 & 65.6 \\
\hline
\end{tabular}

* DBT = dry bulb temperature $\left({ }^{\circ} \mathrm{C}\right) ; \mathrm{RH}=$ relative humidity $(\%)$.

\section{RESULTS AND DISCUSSION}

In the environment subject to full sunlight the coffee seedlings did not emerge in most substrates, and because very few seedlings were obtained this environment was removed from the statistical analyses.

For all parameters evaluated, the relationship between the residual mean squares (RRMS) of the analyses of variance in individual experiments did not exceed the ratio of $7: 1$, therefore allowing the realization of joint experimental analysis (BANZATTO \& KRONKA, 2006) and comparison of cultivation environments.

For all the variables studied, the environments, substrates and their interactions showed significant differences. These results demonstrate that in coffee seedlings there is an influence 
between the types of substrate used and protected environment utilized for growth, formation and development of seedlings, and these factors interact to provide the best type conditions for seedling growth. Interactions between substrates and protected environments were observed in fruit plant seedlings by SANTOS et al. (2011) with jatobazeiro-do-cerrado, COSTA et al. (2010a) with passion fruit and COSTA et al. (2011a) with papaya.

In the evaluation of environmental conditions, it was observed that for the $50 \%$ cattle manure $+50 \%$ vermiculite substrate (S2) that the plants cultivated in the agricultural greenhouse (A1) emerged faster than in the other environments. For seedling in the substrate composed of $1 / 3$ cattle manure $+1 / 3$ substrate commercial $+1 / 3$ vermiculite (S4) greater emergence was observed in A1 than in the black screen with $30 \%$ shading (A4). For the other substrates the seedlings grown in A1 showed faster emergence than those in the environment with black screen and $50 \%$ shading (A2) (Table 3).

There was a small difference in the temperature of environment at the times of sampling (Table 2), however the agricultural greenhouse did not permit the entry of rainwater and may have stored greater amounts of energy at the beginning of the night, which may have resulted in emergence in relation to the black screen with 50\% shading during the experiment. Similar results for temperatures between the non-acclimatized protected environments (greenhouse and screened buildings) were observed by COSTA et al. (2010b) in papaya seedlings and COSTA et al. (2011b) in the formation of yellow passion fruit seedlings. Values of external temperatures and indoor relative humidity in the environment showed no discrepancy, different from that observed by ANDRADE JÚNIOR et al. (2011) for the relative humidity of internal air of an environment with $50 \%$ shading and the external temperature.

Seedlings in the greenhouse, grown in the substrate composed of $1 / 3$ sand $+1 / 3$ cattle manure $+1 / 3$ commercial substrate (S6) emerged faster than those of the black screen with $70 \%$ shading and those grown in the $50 \%$ commercial substrate $+50 \%$ sand substrate (S7) faster than those in the screened environment with 30\% shading (A5) and straw (A6) (Table 3).

However it was verified that the agricultural greenhouse provided suitable conditions for the emergence of coffee seedlings for all substrates studied. In the evaluation of substrates for each cultivation environment, it is noted that in the agricultural greenhouse the coffee seedlings of substrate S2 had higher velocity than those of the other substrates. In the nursery with $50 \%$ black screen emergence was higher in S4 in relation to S5. In the nursery with the aluminized screen, the seedlings of S3 did not differ from S4, and in the 30\% black screen those of S3 did not differ from S2, presenting a higher emergence speed index (ESI) than those of the other substrates. In the 70\% black screen the seedlings in S3 which did not differ from those of S1, S2 and S4 showed greater ESI than those grown in S5, S6 and S7 and in the nursery with straw the seedlings of S3 which did not differ from the S4 and S6, presented greater ESI than those of the other substrates (Table 3).

With the exception of the greenhouse, the seedlings in substrate S3 presented good initial development. For the emergence parameters (EP, AET and AES) there were small differences between the environmental conditions for most of the substrates studied. For the EP of substrates S2, S3 and S7, the AET of substrates S5 and S7, as well as the AES of substrate S6, there was better emergence in the greenhouse than in the $50 \%$ black screen (Table 4). The rapid germination and uniform formation of seedling are highly desirable characteristics in the seedling production process, requiring less time in the nursery environment. However, there is no direct relationship between increased emergence speed and greater seedling vigor.

It was also found that the substrates within each environment showed small differences with regard to the other emergence parameters. In the greenhouse the seedlings in S1 presented higher AET and lower AES; in environments A2 and A4 the seedlings in S5 and S7, as well as in the environment A6 for S7, the PE and AET were lower, consequently resulting in a higher AES (Table 3). The seedlings of these substrates, although presenting a lower percentage, had a shorter average emergence time, where this increased speed is desirable so that the seedlings suffer less influence of adverse environmental conditions. 
TABLE 3. Emergence speed index (ESI), emergence percentage (EP), average emergence time (AET) and average emergence speed (AES) of coffee seedling. Aquidauana, 2010-2011.

\begin{tabular}{|c|c|c|c|c|c|c|}
\hline & $\mathrm{A} 1^{* *}$ & A2 & A3 & $\mathrm{A} 4$ & A5 & A6 \\
\hline & \multicolumn{6}{|c|}{ Emergence speed index } \\
\hline $\mathrm{S} 1 * * *$ & $0.263 \mathrm{Ba}^{*}$ & $0.205 \mathrm{ABb}$ & 0.248 BCab & 0.221 BCab & $0.256 \mathrm{ABab}$ & 0.244 BCab \\
\hline S2 & 0.347 Аа & $0.204 \mathrm{ABb}$ & $0.218 \mathrm{Bcb}$ & $0.259 \mathrm{ABb}$ & $0.254 \mathrm{ABb}$ & $0.249 \mathrm{Bb}$ \\
\hline S3 & $0.274 \mathrm{Ba}$ & $0.184 \mathrm{ABb}$ & $0.311 \mathrm{Aa}$ & $0.298 \mathrm{Aа}$ & $0.278 \mathrm{Aа}$ & $0.314 \mathrm{Aa}$ \\
\hline S4 & $0.264 \mathrm{Ba}$ & $0.213 \mathrm{Aab}$ & $0.264 \mathrm{ABa}$ & $0.195 \mathrm{Cb}$ & $0.232 \mathrm{ABab}$ & $0.258 \mathrm{ABa}$ \\
\hline S5 & $0.223 \mathrm{Ba}$ & $0.151 \mathrm{Bb}$ & $0.200 \mathrm{Cab}$ & $0.168 \mathrm{Cab}$ & $0.205 \mathrm{Bab}$ & $0.189 \mathrm{CDab}$ \\
\hline S6 & $0.273 \mathrm{Ba}$ & $0.208 \mathrm{ABb}$ & 0.223 BCab & 0.221 BCab & $0.216 \mathrm{Bb}$ & $0.262 \mathrm{ABab}$ \\
\hline \multirow[t]{2}{*}{ S7 } & $0.268 \mathrm{Ba}$ & $0.164 \mathrm{ABbc}$ & 0.215 BCab & $0.164 \mathrm{Cbc}$ & $0.216 \mathrm{Bab}$ & $0.156 \mathrm{Dc}$ \\
\hline & \multicolumn{6}{|c|}{ Emergence percentage } \\
\hline $\mathrm{S} 1 * * *$ & 97.6 Аа & 73.9 Аа & $95.3 \mathrm{Aa}$ & 76.6 Аа & 92.9 Аа & $86.8 \mathrm{Aa}$ \\
\hline $\mathrm{S} 2$ & $100.0 \mathrm{Aa}$ & $65.7 \mathrm{ABb}$ & 77.3 Aab & 87.5 Aab & 85.1 Aab & 85.1 Aab \\
\hline S3 & 95.3 Аа & $59.6 \mathrm{ABCb}$ & $92.9 \mathrm{Aa}$ & $92.9 \mathrm{Aa}$ & 92.9 Аа & 95.3 Аa \\
\hline S4 & 81.7 Аa & 77.3 Аа & $82.1 \mathrm{Aa}$ & 75.6 Аа & 87.8 Аа & $85.1 \mathrm{Aa}$ \\
\hline S5 & $80.7 \mathrm{Aa}$ & $38.2 \mathrm{Ca}$ & $74.1 \mathrm{Aa}$ & $43.1 \mathrm{Bb}$ & 80.0 Аа & 73.9 Аа \\
\hline S6 & $95.3 \mathrm{Aa}$ & 79.0 Аа & 78.0 Аа & 87.8 Аа & $88.2 \mathrm{Aa}$ & 92.9 Аа \\
\hline \multirow[t]{2}{*}{ S7 } & $90.2 \mathrm{Aa}$ & 48.0 BCbc & $71.8 \mathrm{Aab}$ & 49.8 Bbc & 86.8 Aa & 46.5 Bc \\
\hline & \multicolumn{6}{|c|}{ Average emergence time, days } \\
\hline $\mathrm{S} 1 * * *$ & $30.18 \mathrm{Aa}$ & $30.07 \mathrm{Aa}$ & 30.17 Аа & 30.01 Aba & $30.19 \mathrm{Aa}$ & $30.12 \mathrm{Aa}$ \\
\hline S2 & $29.85 \mathrm{Ba}$ & $29.92 \mathrm{ABa}$ & 30.09 Аа & 30.10 Аа & $30.10 \mathrm{Aa}$ & 30.11 Аа \\
\hline S3 & $30.00 \mathrm{ABa}$ & 29.85 АВСа & $29.95 \mathrm{Aa}$ & $30.04 \mathrm{Aa}$ & $30.12 \mathrm{Aa}$ & $29.97 \mathrm{Aa}$ \\
\hline S4 & $30.02 \mathrm{ABa}$ & $30.06 \mathrm{Aa}$ & 29.96 Аа & $30.02 \mathrm{Aa}$ & 30.16 Аа & 30.09 Аа \\
\hline S5 & $30.06 \mathrm{ABa}$ & $29.58 \mathrm{Cb}$ & $29.99 \mathrm{Aa}$ & $29.69 \mathrm{Cb}$ & $30.07 \mathrm{Aa}$ & $30.02 \mathrm{Aa}$ \\
\hline S6 & $30.13 \mathrm{ABa}$ & $30.09 \mathrm{Aa}$ & $30.05 \mathrm{Aa}$ & $30.18 \mathrm{Aa}$ & $30.18 \mathrm{Aa}$ & $30.20 \mathrm{Aa}$ \\
\hline \multirow[t]{2}{*}{ S7 } & $30.11 \mathrm{ABa}$ & 29.74 BCbc & 29.97 Aab & 29.72 BCbc & $30.15 \mathrm{Aa}$ & $29.66 \mathrm{Bc}$ \\
\hline & \multicolumn{6}{|c|}{ Average emergence speed, days ${ }^{-1}$} \\
\hline S1 & $0.0331 \mathrm{Ba}$ & $0.0333 \mathrm{Ca}$ & $0.0331 \mathrm{Aa}$ & 0.0333 BCa & $0.0331 \mathrm{Aa}$ & $0.0332 \mathrm{Ba}$ \\
\hline S2 & 0.0335 Аа & $0.0334 \mathrm{BCa}$ & 0.0332 Аа & $0.0332 \mathrm{Ca}$ & $0.0332 \mathrm{Aa}$ & $0.0332 \mathrm{Ba}$ \\
\hline S3 & $0.0333 \mathrm{ABa}$ & $0.0335 \mathrm{ABCa}$ & 0.0334 Аа & 0.0333 BCa & $0.0332 \mathrm{Aa}$ & $0.0334 \mathrm{ABa}$ \\
\hline S4 & $0.0333 \mathrm{ABa}$ & $0.0333 \mathrm{Ca}$ & 0.0334 Аа & $0.0333 \mathrm{BCa}$ & $0.0332 \mathrm{Aa}$ & $0.0332 \mathrm{Ba}$ \\
\hline S5 & $0.0333 \mathrm{ABa}$ & $0.0338 \mathrm{Aa}$ & $0.0333 \mathrm{Aa}$ & $0.0337 \mathrm{Aa}$ & $0.0333 \mathrm{Aa}$ & $0.0333 \mathrm{Ba}$ \\
\hline S6 & $0.0332 \mathrm{ABb}$ & $0.0332 \mathrm{Ca}$ & $0.0333 \mathrm{Ab}$ & $0.0331 \mathrm{Ca}$ & $0.0331 \mathrm{Ab}$ & $0.0331 \mathrm{Bb}$ \\
\hline S7 & $0.0332 \mathrm{ABa}$ & $0.0336 \mathrm{ABa}$ & 0.0334 Аа & 0.0336 Aba & $0.0332 \mathrm{Aa}$ & $0.0337 \mathrm{Aa}$ \\
\hline
\end{tabular}

*Equal upper-case letters in the columns and lower-case letters in the lines, for each factor, do not differ according to the Tukey test at $5 \%$ probability (data transformed in root of $\mathrm{x}+0.5$ ); ${ }^{* *} \mathrm{~A} 1=$ agricultural greenhouse; $\mathrm{A} 2=$ black screen with 50\% shading; A3 = aluminized screen with 50\% shading; A4 = black screen with $30 \%$ shading; A5 = black screen with 70\% shading; A6 = nursery with buriti straw; *** S1 $=50 \%$ cattle manure $+50 \%$ commercial substrate; S2 $=50 \%$ cattle manure $+50 \%$ vermiculite; S3 $=50 \%$ commercial substrate $+50 \%$ vermiculite; S4 $=1 / 3$ cattle manure + $1 / 3$ commercial substrate $+1 / 3$ vermiculite; S5 $=50 \%$ cattle manure $+50 \%$ sand; S6 $=1 / 3$ sand $+1 / 3$ cattle manure + $1 / 3$ commercial substrate and S7 $=50 \%$ commercial substrate $+50 \%$ sand.

The smaller seedlings at 90 and 120 DAS, as well as the smallest leaf pairs at 120 days were observed in the substrate containing 50\% commercial substrate $+50 \%$ vermiculite (S3) and 50\% Vida Verde $+50 \%$ sand (S7) in all growing environments. For these substrates the growing environments did not show significant differences, as well as plant height in the substrate with $1 / 3$ sand $+1 / 3$ cattle manure $+1 / 3$ commercial substrate (S6) (Table 4). ANDRADE NETO et al. (1999) when evaluating coffee seedlings obtained better results of height when using $80 \%$ cattle manure. In the present study 50\% cattle manure resulted in the height and number of leaves that can characterize high-quality seedlings.

The substrates composed of $50 \%$ cattle manure $+50 \%$ Vida Verde (S1), $1 / 3$ sand $+1 / 3$ cattle manure $+1 / 3$ commercial substrate (S6) and 1/3 cattle manure $+1 / 3$ commercial substrate $+1 / 3$ 
vermiculite (S4) led to high-quality seedlings with regards the height and number of leaves in all growing environments (Table 4).

In $\mathrm{S} 1$ the seedlings from the environment with the thermo-reflective aluminized screen with $50 \%$ shading (A3), which did not differ from the agricultural greenhouse (A1), were taller than those grown in the other environments and with respect to the number of leaves, these were superior to the seedlings in the environments with black screens of 50\% (A2) and 30\% shading (A4) at 120 DAF (Table 4). BRAUN et al. (2007), when evaluating "Conilon" coffee seedlings grown in different levels of shading, found the best results in the environment with $75 \%$ shading and in the present study for S1 the best results were found for the two screens with $50 \%$ shading, as verified by PAIVA et al. (2003) in arabica coffee seedlings.

For substrate S4, the seedlings of the straw nursery (A6), which did not differ from seedlings of the $70 \%$ black screen (A5), were shorter than in other environments and had fewer leaf pairs than the seedlings grown in the greenhouse (A1) and 30\% black screen (Table 4). DIAS et al. (2009) evaluated the proportions of organic material in the formation of the coffee seedlings and showed that cattle manure in the ratio of 20 and $40 \%$ results in more leaf pairs (5.33 and 5.25, respectively), and in the case of $60 \%$ these authors obtained 4.63 leaf pairs.

In the assessment of coffee seedlings at different shading levels (22, 50 and 88\%) and full sunlight, Tatagiba et al. (2010) found that the best vegetative growth was at 22 and 50\% shading.

Under different shading levels (full sunlight, 50 and 80\%), CARELLI et al. (1999) observed shorter coffee seedlings when grown under $30 \%$ shading, as well as significant differences between plants in full sunlight and 50\% shading. However, PAIVA et al. (2003) observed increased growth of arabica coffee seedlings in 50\% shade, while BRAUN et al. (2007) found that conilon coffee seedlings were taller with 50 and $75 \%$ shading when compared with seedlings subjected to $30 \%$ shading and full sunlight.

DIAS \& MELO (2009) evaluated the proportion of organic material (composted cattle manure, composted turkey litter and composted tobacco residue) in the artificial substrate (BioPlant-Café ${ }^{\circledR}$ ) for the production of coffee seedlings in tubes, and found that there was an increase in number of true leaf pairs among organic materials, where the turkey litter and cattle manure presented the highest number of leaf pairs (6.41 and 6.25). In the present study, the substrates with cattle manure (S1, S4 and S6) showed the best results in terms of number of leaves, confirming the data obtained in DIAS \& MELO (2009) study.

As was observed for the height and number of leaves (Table 4) and for dry phytomasses (Table 5), smaller diameters were recorded for substrates S3 and S7 in all growing environments (Table 4). TATAGIBA et al. (2010), when evaluating stem diameter of arabica coffee seedlings under different levels of shading (full sunlight, 22, 50 and $88 \%$ shading), found that levels of shading did not significantly affect stem diameter of the seedlings at 40 days, but at 80 and 120 days differences were observed among averages of the different shadings. It was found that $88 \%$ shading resulted in the smallest diameter, and in full sunlight and $22 \%$ and $50 \%$ shading the stem diameter did not differ significantly.

The growing environments showed small differences with regards to stem diameter. For most substrates, the black and aluminized screened environments, both with 50\% shading, resulted in plants with smaller diameters (Table 4). PAIVA et al. (2003) evaluated the production of arabica coffee seedlings under different levels of shading (full sunlight, 30, 50 and 90\% shading), and observed larger stem diameters of seedlings under $90 \%$ shading.

In the study of percentage of organic material in the substrate for production of coffee seedlings in tubes, DIAS \& MELO (2009) found that with respect to stem diameter, the cattle manure and turkey litter showed similar results. CUNHA et al. (2002) found that the stem diameter of coffee plants can be influenced by the type of substrate used, and that the use of tubes with volumetric capacity of $120 \mathrm{~mL}$ resulted in increased stem diameters $(2.61 \mathrm{~mm})$. These authors therefore suggest that the best substrate for coffee seedling production is Plantmax ${ }^{\circledR}$ plus 
Osmocote $^{\circledR}$, followed by $50 \%$ cattle manure, $30 \%$ subsoil dirt and $20 \%$ of a mixture composed of $50 \%$ vermiculite, $25 \%$ coarse sand and $25 \%$ carbonized rice hulls.

TABLE 4. Plant height at 90 DAS (PH1), plant height at 120 DAS (PH2), number of leaf pairs (NPF) and stem diameter (SD) of coffee seedlings. Aquidauana - MS, 2010-2011.

\begin{tabular}{|c|c|c|c|c|c|c|}
\hline & $\mathrm{A} 1^{* *}$ & $\mathrm{~A} 2$ & A3 & A4 & A5 & A6 \\
\hline & \multicolumn{6}{|c|}{ Plant height at 90 DAS, cm } \\
\hline $\mathrm{S} 1 * * *$ & 7.10 Aab & 6.74 Aab & 7.47 Аа & $6.15 \mathrm{Ab}$ & 7.59 Аа & $6.13 \mathrm{Ab}$ \\
\hline S2 & 5.28 ВСс & 6.67 Aab & $7.55 \mathrm{Aа}$ & 6.60 Aab & 6.76 ABab & $5.55 \mathrm{ABbc}$ \\
\hline S3 & $4.50 \mathrm{Ca}$ & $4.85 \mathrm{Ca}$ & 4.65 Ca & 4.13 Ba & 4.74 DEa & 4.85 Ba \\
\hline S4 & $6.77 \mathrm{Aa}$ & 6.17 ABab & $6.67 \mathrm{ABa}$ & $6.35 \mathrm{Aa}$ & 6.37 ABCa & $5.10 \mathrm{ABb}$ \\
\hline S5 & $6.17 \mathrm{ABa}$ & $4.90 \mathrm{BCb}$ & 6.07 Bab & $6.03 \mathrm{Aab}$ & 5.17 CDEab & 5.01 ABab \\
\hline S6 & $7.00 \mathrm{Aab}$ & 7.08 Аа & 6.13 Bab & $7.10 \mathrm{Aa}$ & 5.97 BCDab & $5.82 \mathrm{ABb}$ \\
\hline \multirow[t]{2}{*}{ S7 } & 4.14 Ca & $3.80 \mathrm{Ca}$ & 4.37 Ca & $3.58 \mathrm{Ba}$ & $4.37 \mathrm{Fa}$ & $3.20 \mathrm{Ca}$ \\
\hline & \multicolumn{6}{|c|}{ Plant height at 120 DAS, cm } \\
\hline $\mathrm{S} 1 * * *$ & 12.05 Aab & $11.28 \mathrm{Ab}$ & $13.43 \mathrm{Aa}$ & $10.92 \mathrm{Ab}$ & $10.65 \mathrm{Ab}$ & $10.78 \mathrm{Ab}$ \\
\hline S2 & $5.60 \mathrm{Cc}$ & $10.72 \mathrm{Aa}$ & $11.80 \mathrm{ABa}$ & $10.11 \mathrm{ABab}$ & $11.18 \mathrm{Aa}$ & $8.48 \mathrm{Bb}$ \\
\hline S3 & $4.75 \mathrm{Ca}$ & $5.11 \mathrm{Ba}$ & $5.18 \mathrm{Da}$ & $5.20 \mathrm{Ca}$ & $5.06 \mathrm{Ca}$ & $5.52 \mathrm{Ca}$ \\
\hline S4 & $11.88 \mathrm{Aa}$ & $11.95 \mathrm{Aa}$ & $11.88 \mathrm{ABa}$ & $11.78 \mathrm{Aa}$ & 10.44 Aab & $9.73 \mathrm{ABb}$ \\
\hline S5 & $9.87 \mathrm{Ba}$ & $6.20 \mathrm{Bb}$ & $8.73 \mathrm{Ca}$ & 8.67 Ba & $8.18 \mathrm{Ba}$ & $9.48 \mathrm{ABa}$ \\
\hline S6 & $10.73 \mathrm{ABa}$ & $11.42 \mathrm{Aa}$ & 9.93 ВСa & 10.73 Аа & $10.78 \mathrm{Aa}$ & $10.05 \mathrm{ABa}$ \\
\hline \multirow[t]{2}{*}{ S7 } & $4.63 \mathrm{Ca}$ & 4.30 Ba & $4.73 \mathrm{Da}$ & $4.03 \mathrm{Ca}$ & $4.71 \mathrm{Ca}$ & $4.20 \mathrm{Ca}$ \\
\hline & \multicolumn{6}{|c|}{ Number of leaf pairs at 120 DAS } \\
\hline $\mathrm{S} 1 * * *$ & 4.60 ABab & $3.93 \mathrm{Ab}$ & $4.85 \mathrm{Aa}$ & $3.90 \mathrm{Bb}$ & 4.60 Aab & 4.65 Aab \\
\hline S2 & $1.00 \mathrm{Cc}$ & 4.20 Aab & $4.80 \mathrm{Aa}$ & $4.58 \mathrm{ABa}$ & 4.83 Аа & $3.62 \mathrm{Bb}$ \\
\hline S3 & $1.00 \mathrm{Ca}$ & $1.00 \mathrm{Ca}$ & $1.00 \mathrm{Ba}$ & $1.00 \mathrm{Ca}$ & $1.00 \mathrm{Ca}$ & $1.50 \mathrm{Ca}$ \\
\hline S4 & 4.87 Аа & 4.52 Aab & 4.42 Aab & 4.72 Аа & 4.18 ABab & $3.78 \mathrm{Bb}$ \\
\hline S5 & $3.98 \mathrm{Bb}$ & $2.50 \mathrm{Bc}$ & 4.10 Aab & 4.80 Аа & $3.77 \mathrm{Bb}$ & $3.75 \mathrm{Bb}$ \\
\hline S6 & 4.70 ABa & 4.20 Aab & 4.12 Aab & 4.63 АBa & 4.62 Aab & $3.90 \mathrm{ABb}$ \\
\hline \multirow[t]{2}{*}{ S7 } & $1.00 \mathrm{Ca}$ & $1.00 \mathrm{Ca}$ & $1.00 \mathrm{Ba}$ & $1.00 \mathrm{Ca}$ & $1.00 \mathrm{Ca}$ & $1.00 \mathrm{Ca}$ \\
\hline & \multicolumn{6}{|c|}{ Stem diameter at $120 \mathrm{DAS}, \mathrm{mm}$} \\
\hline S1 & $2.85 \mathrm{ABbc}$ & $2.64 \mathrm{Ac}$ & $2.85 \mathrm{Abc}$ & $3.25 \mathrm{Aa}$ & 3.07 Aab & 3.10 Aab \\
\hline S2 & $2.10 \mathrm{Cb}$ & $2.84 \mathrm{Aa}$ & $2.71 \mathrm{Aa}$ & $3.05 \mathrm{Aa}$ & $3.05 \mathrm{Aa}$ & $2.84 \mathrm{Aa}$ \\
\hline S3 & 2.12 Cab & 2.12 BCab & $1.83 \mathrm{Bb}$ & $2.03 \mathrm{Cab}$ & $2.33 \mathrm{Ca}$ & $2.28 \mathrm{Ba}$ \\
\hline S4 & 3.23 Аа & $2.81 \mathrm{Ab}$ & $2.85 \mathrm{Ab}$ & $3.24 \mathrm{Aa}$ & 2.99 ABab & 3.08 Aab \\
\hline S5 & 2.62 Bab & 2.21 Bc & $2.57 \mathrm{Abc}$ & 2.66 Bab & 2.64 BCab & $2.94 \mathrm{Aa}$ \\
\hline S6 & $2.63 \mathrm{Bb}$ & $2.62 \mathrm{Ab}$ & $2.49 \mathrm{Ab}$ & $3.15 \mathrm{Aa}$ & 3.13 Аа & $3.03 \mathrm{Aa}$ \\
\hline S7 & 2.07 Cab & $1.81 \mathrm{Cb}$ & 1.96 Bab & $1.95 \mathrm{Cab}$ & $2.27 \mathrm{Ca}$ & 1.96 Bab \\
\hline
\end{tabular}

*Equal upper-case letters in the columns and lower-case letters in the lines, for each factor, do not differ according to the Tukey test at $5 \%$ probability (data transformed in root of $\mathrm{x}+0.5$ ); **A 1 = agricultural greenhouse; $\mathrm{A} 2$ = black screen with $50 \%$ shading; $\mathrm{A} 3=$ aluminized screen with 50\% shading; A4 = black screen with 30\% shading; A5 = black screen with 70\% shading; A6 = nursery with buriti straw; $* * * \mathrm{~S} 1=50 \%$ cattle manure $+50 \%$ commercial substrate; S2 $=50 \%$ cattle manure $+50 \%$ vermiculite; S3 $=50 \%$ commercial substrate $+50 \%$ vermiculite; $\mathrm{S} 4=1 / 3$ cattle manure $+1 / 3$ commercial substrate $+1 / 3$ vermiculite; S5 $=50 \%$ cattle manure $+50 \%$ valve; S6 $=1 / 3$ sand $+1 / 3$ cattle manure $+1 / 3$ commercial substrate and $\mathrm{S} 7=50 \%$ commercial substrate $+50 \%$ sand.

In all environments, the substrates S3 (50\% commercial substrate $+50 \%$ vermiculite) and S7 ( $50 \%$ commercial substrate $+50 \%$ sand) were not suitable for production of coffee seedlings, since plants accumulated smaller amounts of dry phytomass (Table 5). These two substrates were composed of $50 \%$ commercial substrate, with very high iron concentrations and an elevated $\mathrm{C} / \mathrm{N}$ ratio (Table 1). This elevated relationship resulted in nitrogen immobilization in function of the high $\mathrm{N}$ demand of decomposing organisms, promoting low mineralization of this element which is not sufficient to meet the needs of the plant. 
All substrates containing cattle manure (S1, S2, S4, S5 and S6), with the exception of S2 in the agricultural greenhouse, generated high-quality seedlings, with good characteristics of shoot, root and total dry biomass (Table 5). Independent of the quantity of manure utilized (33.33 and $50 \%$ ), it was beneficial. Papaya seedlings submitted to different concentrations of organic compounds with manure, found increasing linear equations, where the largest concentration tested (40\%) was best for the plant height, root length, number of leaves/plant, and shoot, root and total dry masses (MENDONÇA et al., 2007).

In the formation of coffee seedlings (Coffea arabica L., cultivar Acaiá Cerrado lineage 1474) produced in $120 \mathrm{~mL}$ tubes and a screened environment made of a black screen with $50 \%$ shading, DIAS \& MELO (2009) utilized a substrate mixture composed of BioPlant-café with 0, 20, 40, 60, 80 and $100 \%$ of composted cattle manure, composted turkey litter and composted tobacco residues, just as DIAS et al. (2009) with 0, 20, 40, 60, 80 and 100\% of cattle manure, earthworm castings and turkey litter, both experiments fertilized with Osmocote ${ }^{\circledR}$ (NPK 15-09-12), it was verified that in substrates containing cattle manure the smaller the concentration of this component, the greater the shoot, root and total dry masses. This was different from that observed in the present study performed in a similar environment, where in concentrations of 25,33 and $50 \%$ the cattle manure, composted for 30 days, good shoot, root and total development was observed. It was therefore verified that when cattle manure is composted it can be used in greater proportions, forming seedling of excellent quality and vigor.

ANDRADE NETO et al. (1999) claimed that the best organic material for the production of shoot dry mass is cattle manure at a concentration of $80 \%$, fertilized with Osmocote ${ }^{\circledR}$. CARVALHO (1978) evaluated substrates for production of coffee seedlings in plastic bags and observed more dry matter when utilizing $30 \%$ cattle manure fertilized with simple superphosphate $\left(0.85 \mathrm{~kg}\right.$ of $\mathrm{P}_{2} \mathrm{O}_{5} \mathrm{~m}^{-3}$ of substrate), and $36.38 \%$ earthworm castings fertilized with Osmocote ${ }^{\circledR}$. Assessing the total dry mass of coffee seedlings in the present experiment, the cattle manure concentrations of 50 and 30\% provided the best results, different from those observed by ANDRADE NETO et al. (1999) and corroborating with those of CARVALHO (1978).

With the exception of substrate 7 in environment A6, the survival percentage of coffee seedlings was greater in environments A1 (agricultural greenhouse), A5 (black screen with 70\% shading) and A6 (nursery with buriti straw) (Table 5). TATAGIBA et al. (2010) verified at 120 DAS that the shading levels of 22 and $50 \%$ did not differ with regards to total dry matter of 3.30 and $3.41 \mathrm{~g}$, respectively, in coffee seedlings produced in bags measuring 15.0 x $25.0 \mathrm{~cm}$, where these values are greater than those obtained in the present study in which bags measuring $10 \times 15$ $\mathrm{cm}$ were used. When compared with the present study, besides the smaller recipients, these results may be explained by the influence of high temperatures during the experimental period, since the coffee crop is sensitive to excessive heat.

Arabica coffee seedlings grown in full sun in the cerrado/pantanal ecotone did not develop properly when subjected to exposure to full sunlight, with survival rates close to zero. However, the seedlings grown in the agricultural greenhouse with 30 and $70 \%$ shading and in the nursery covered with buriti straw, except for substrate S7 in this environment, showed excellent indices of survival and development. TATAGIBA et al. (2010) confirmed that coffee seedlings grown in full sun, with intense exposure to solar radiation without any protection, a practice often used by producers, can cause a reduction in shoot dry matter, forming less vigorous seedlings, as observed in the present study where plants did not develop.

In conilon coffee seedlings produced at different shading levels, BRAUN et al. (2007) observed irregular development of shoots in seedlings grown in full sunlight, where these were weak and not able to withstand environmental conditions in the field. Also according to the same authors, environments with $75 \%$ shading showed the greatest average of shoot dry mass. 
TABLE 5. Shoot dry mass (SDM), root dry mass (DRM), total dry mass (TDM) and percentage of survival (POS) of coffee seedlings. Aquidauana - MS, 2010-2011.

\begin{tabular}{|c|c|c|c|c|c|c|}
\hline & $\mathrm{A} 1 * *$ & A2 & A3 & A4 & A5 & A6 \\
\hline & \multicolumn{6}{|c|}{ Shoot dry mass, g } \\
\hline $\mathrm{S} 1 * * *$ & $1.32 \mathrm{Aa}$ & $1.14 \mathrm{Aa}$ & $1.41 \mathrm{Aa}$ & $1.23 \mathrm{Aa}$ & $1.32 \mathrm{Aa}$ & $1.17 \mathrm{ABa}$ \\
\hline $\mathrm{S} 2$ & $0.16 \mathrm{Cd}$ & 1.10 Abc & $1.50 \mathrm{Aa}$ & 1.16 Abc & $1.25 \mathrm{Aab}$ & 0.89 ВСс \\
\hline S3 & $0.13 \mathrm{Ca}$ & $0.13 \mathrm{Ba}$ & $0.12 \mathrm{Ca}$ & $0.13 \mathrm{Ca}$ & $0.14 \mathrm{Ca}$ & $0.18 \mathrm{Da}$ \\
\hline $\mathrm{S} 4$ & $1.29 \mathrm{ABa}$ & $1.27 \mathrm{Aa}$ & $1.22 \mathrm{Aa}$ & $1.32 \mathrm{Aa}$ & $1.20 \mathrm{Aa}$ & $1.28 \mathrm{Aa}$ \\
\hline S5 & $1.00 \mathrm{ABa}$ & $0.21 \mathrm{Bc}$ & $0.65 \mathrm{Bb}$ & $0.82 \mathrm{Bab}$ & $0.67 \mathrm{Bb}$ & $0.84 \mathrm{Cab}$ \\
\hline S6 & $0.97 \mathrm{Bab}$ & $1.07 \mathrm{Aa}$ & $0.74 \mathrm{Bb}$ & $1.04 \mathrm{ABab}$ & $1.11 \mathrm{Aa}$ & $1.08 \mathrm{ABCa}$ \\
\hline \multirow[t]{2}{*}{ S7 } & $0.11 \mathrm{Ca}$ & $0.08 \mathrm{Ba}$ & $0.10 \mathrm{Ca}$ & $0.08 \mathrm{Ca}$ & $0.14 \mathrm{Ca}$ & $0.11 \mathrm{Da}$ \\
\hline & \multicolumn{6}{|c|}{ Root dry mass, g } \\
\hline $\mathrm{S} 1 * * *$ & $0.24 \mathrm{ABC}$ & $0.31 \mathrm{Abc}$ & $0.34 \mathrm{Ab}$ & $0.47 \mathrm{Aa}$ & $0.34 \mathrm{Abc}$ & $0.26 \mathrm{Abc}$ \\
\hline $\mathrm{S} 2$ & $0.09 \mathrm{CDc}$ & $0.24 \mathrm{Aab}$ & $0.34 \mathrm{Aa}$ & $0.28 \mathrm{Cab}$ & $0.26 \mathrm{Aab}$ & $0.22 \mathrm{ABb}$ \\
\hline S3 & $0.08 \mathrm{Da}$ & $0.08 \mathrm{Ba}$ & $0.09 \mathrm{Ba}$ & $0.10 \mathrm{Da}$ & $0.10 \mathrm{Ba}$ & $0.14 \mathrm{BCa}$ \\
\hline S4 & $0.30 \mathrm{Aab}$ & 0.29 Aab & 0.34 Aab & $0.39 \mathrm{ABa}$ & $0.36 \mathrm{Aab}$ & $0.27 \mathrm{Ab}$ \\
\hline S5 & $0.15 \mathrm{BCDb}$ & $0.07 \mathrm{Bb}$ & $0.28 \mathrm{Aa}$ & $0.29 \mathrm{BCa}$ & $0.30 \mathrm{Aa}$ & $0.28 \mathrm{Aa}$ \\
\hline S6 & $0.20 \mathrm{ABC}$ & $0.32 \mathrm{Aab}$ & $0.27 \mathrm{Abc}$ & 0.38 ABCa & $0.26 \mathrm{Abc}$ & $0.26 \mathrm{Abc}$ \\
\hline \multirow[t]{2}{*}{ S7 } & $0.06 \mathrm{Da}$ & $0.05 \mathrm{Ba}$ & $0.07 \mathrm{Ba}$ & $0.05 \mathrm{Da}$ & $0.08 \mathrm{Ba}$ & $0.07 \mathrm{Ca}$ \\
\hline & \multicolumn{6}{|c|}{ Total dry mass, g } \\
\hline $\mathrm{S} 1 * * *$ & $1.55 \mathrm{ABa}$ & $1.45 \mathrm{Aa}$ & $1.75 \mathrm{Aa}$ & $1.69 \mathrm{Aa}$ & $1.65 \mathrm{Aa}$ & $1.44 \mathrm{ABa}$ \\
\hline $\mathrm{S} 2$ & $0.25 \mathrm{Dd}$ & $1.34 \mathrm{Abc}$ & $1.84 \mathrm{Aa}$ & 1.44 ABbc & $1.51 \mathrm{Aab}$ & $1.11 \mathrm{Bc}$ \\
\hline S3 & $0.21 \mathrm{Da}$ & $0.20 \mathrm{Ba}$ & $0.21 \mathrm{Ca}$ & $0.23 \mathrm{Ca}$ & $0.24 \mathrm{Ca}$ & $0.32 \mathrm{Ca}$ \\
\hline S4 & $1.59 \mathrm{Aa}$ & $1.56 \mathrm{Aa}$ & $1.57 \mathrm{Aa}$ & $1.71 \mathrm{Aa}$ & $1.56 \mathrm{Aa}$ & $1.55 \mathrm{Aa}$ \\
\hline S5 & $1.15 \mathrm{Ca}$ & $0.28 \mathrm{Bb}$ & $0.93 \mathrm{Ba}$ & $1.10 \mathrm{Ba}$ & $0.97 \mathrm{Ba}$ & $1.12 \mathrm{Ba}$ \\
\hline S6 & 1.17 BCab & 1.39 Aab & $1.01 \mathrm{Bb}$ & $1.42 \mathrm{ABa}$ & 1.37 Aab & $1.34 \mathrm{ABab}$ \\
\hline \multirow[t]{2}{*}{ S7 } & $0.17 \mathrm{Da}$ & $0.14 \mathrm{Ba}$ & $0.17 \mathrm{Ca}$ & $0.13 \mathrm{Ca}$ & $0.21 \mathrm{Ca}$ & $0.18 \mathrm{Ca}$ \\
\hline & \multicolumn{6}{|c|}{ Percentage of survival } \\
\hline $\mathrm{S} 1$ & $100.00 \mathrm{Aa}$ & $80.00 \mathrm{Aa}$ & $95.00 \mathrm{Aa}$ & $85.00 \mathrm{ABa}$ & $100.00 \mathrm{Aa}$ & $80.00 \mathrm{Aa}$ \\
\hline $\mathrm{S} 2$ & $100.00 \mathrm{Aa}$ & $75.00 \mathrm{ABa}$ & $70.00 \mathrm{ABa}$ & $70.00 \mathrm{ABa}$ & $85.00 \mathrm{Aa}$ & $90.00 \mathrm{Aa}$ \\
\hline S3 & $90.00 \mathrm{Aa}$ & $65.00 \mathrm{ABCa}$ & $85.00 \mathrm{ABa}$ & $70.00 \mathrm{ABa}$ & $95.00 \mathrm{Aa}$ & $90.00 \mathrm{Aa}$ \\
\hline S4 & $90.00 \mathrm{Aa}$ & $75.00 \mathrm{ABa}$ & $95.00 \mathrm{Aa}$ & $80.00 \mathrm{ABa}$ & $95.00 \mathrm{Aa}$ & $85.00 \mathrm{Aa}$ \\
\hline S5 & $95.00 \mathrm{Aa}$ & $30.00 \mathrm{Cb}$ & $45.00 \mathrm{Bb}$ & $50.00 \mathrm{Bb}$ & $90.00 \mathrm{Aa}$ & $90.00 \mathrm{Aa}$ \\
\hline S6 & $100.00 \mathrm{Aa}$ & $85.00 \mathrm{Aa}$ & $75.00 \mathrm{ABa}$ & $95.00 \mathrm{Aa}$ & $75.00 \mathrm{Aa}$ & $95.00 \mathrm{Aa}$ \\
\hline S7 & $95.00 \mathrm{Aa}$ & 35.00 BCbc & 60.00 ABab & $65.00 \mathrm{ABab}$ & $85.00 \mathrm{Aa}$ & $20.00 \mathrm{Bc}$ \\
\hline
\end{tabular}

*Equal upper-case letters in the columns and lower-case letters in the lines, for each factor, do not differ according to the Tukey test at $5 \%$ probability (data transformed in root of $\mathrm{x}+0.5$ ); ${ }^{* *} \mathrm{~A} 1=$ agricultural greenhouse; $\mathrm{A} 2$ = black screen with $50 \%$ shading; $\mathrm{A} 3=$ aluminized screen with $50 \%$ shading; A4 = black screen with $30 \%$ shading; A5 = black screen with $70 \%$ shading; A6 = nursery with buriti straw; $* * * \mathrm{~S} 1=50 \%$ cattle manure $+50 \%$ commercial substrate; S2 $=50 \%$ cattle manure $+50 \%$ vermiculite; $\mathrm{S} 3=50 \%$ commercial substrate $+50 \%$ vermiculite; $\mathrm{S} 4=1 / 3$ cattle manure $+1 / 3$ commercial substrate $+1 / 3$ vermiculite; S5 $=50 \%$ cattle manure $+50 \%$ valve; $\mathrm{S} 6=1 / 3$ sand $+1 / 3$ cattle manure $+1 / 3$ commercial substrate and $\mathrm{S} 7=50 \%$ commercial substrate $+50 \%$ sand .

\section{CONCLUSIONS}

The substrates containing 50\% cattle manure associated with vermiculite or the commercial substrate are indicated for production of coffee seedlings. Substrates containing $50 \%$ sand caused an increase in the mortality percentage of the seedlings, especially when mixed with the commercial substrate.

For this experiment did not use fertigation and the cattle manure provided nutrients necessary for plant growth. The use of two daily irrigations may have leached small amounts of nutrients available in other substrates. 
Screened environments with 30, 50 and 70\% shading are recommended to produce highquality seedlings. It is not recommended to produce coffee seedlings in full sunlight in the region of Aquidauana, independent of the type of substrate used.

\section{REFERENCES}

ANDRADE JÚNIOR, A. S.; DAMASCENO, L. M. O.; DIAS, N. S.; GHEVY, H. R., GUISELINI, C. Climate variations in greenhouse cultivated with gerbera and relationship with external conditions. Engenharia Agrícola, Jaboticabal, v. 31, n. 5, p. 857-867, 2011.

ANDRADE NETO, A.; MENDES, A. N. G.; GUIMARÃES, P. T. G. Avaliação de substratos alternativos e tipos de adubação para a produção de mudas de cafeeiro (Coffea arabica L.) em tubetes. Ciência e Agrotecnologia, Lavras, v. 23, n. 2, p. 270-280, 1999.

BANZATTO, D. A.; KRONKA, S. N. Experimentação agrícola. 4. ed. Jaboticabal: FUNEP/ UNESP, 2006. 237 p.

BRAUN, H., ZONTA, J. H.; LIMA, J. S. S.; REIS, E. F. Produção de mudas de café conilon propagadas em diferentes níveis de sombreamento. IDESIA, v. 25, n. 3, p. 85-91, 2007.

CARELLI, M. L.C; FAHL, J. I.; TRIVELIN, P. C. O.; VOLTAN, R. B. Q. Carbon isotope discrimination and gas exchange in coffee species grown under different irradiance regimes. Revista Brasileira de Fisiologia Vegetal, Campinas, v. 11, n. 2, p. 63-68, 1999.

CARRIJO, C.; MARTINS, R. C. C.; MARTINS, I. S.; LANDAHL, D. T.; MATOS, J. M. de M.; NAKANO, T. Y. R. Estabelecimento de Eriotheca pubescens (Bombacaceae) por meio de semeadura direta e de mudas em cascalheira. CERNE, Lavras, v. 15, n. 3, p. 365-370, 2009.

CARVALHO, M. M. Formação de mudas. Informativo Agropecuário, Belo Horizonte, v. 4, n. 44, p. 14-18, 1978.

COSTA E.; RODRIGUES E. T.; ALVES V. B.; SANTOS, L. C. R.; VIEIRA L. C. R. Efeitos da ambiência, recipientes e substratos no desenvolvimento de mudas de maracujazeiro-amarelo em Aquidauana - MS. Revista Brasileira de Fruticultura, Jaboticabal, v. 31, n. 1, p. 236-244, 2009.

COSTA, E. ; GOMES, V. A.; LEAL, P. A. M.; ABOT, A. R.; FERNANDES, C. D. Formação de mudas de mamão em ambientes de cultivo protegido em diferentes substratos. Revista Ceres, Viçosa, v. 57, n. 5, p. 679-685, 2010 b.

COSTA, E. ; SANTOS, L. C. R.; CARVALHO, C.; LEAL, P. A. M.; GOMES, V. A. Volumes de substratos comerciais, solo e composto orgânico afetando a formação de mudas de maracujazeiroamarelo em diferentes ambientes de cultivo. Revista Ceres, Viçosa, v. 58, n.2, p. 216-222, 2011 b.

COSTA, E.; LEAL, P. A. M.; MESQUITA, V. A. G.; SASSAQUI, A. R. Efeitos do Organosuper® e do ambiente protegido na formação de mudas de mamoeiro. Engenharia Agrícola, Jaboticabal, v. 31, n. 1, p. 41-55, 2011 a.

COSTA, E.; LEAL, P. A. M.; SASSAQUI, A. R.; GOMES, V. do A. G. Doses de composto orgânico comercial na composição de substratos para a produção de mudas de maracujazeiro em diferentes tipos de cultivo protegido. Engenharia Agrícola, Jaboticabal, v. 30, n. 5, p. 776-787, 2010 a.

CUNHA, R. L. DA; SOUZA, C. A. S.; NETO, A. A.; MELÓ, B.; CORREA, J. F. Avaliação de substratos e tamanhos de recipientes na formação de mudas de cafeeiros (coffea arábica) em tubetes. Ciência Agrotécnica, Lavras, v. 26, n. 1, p. 7-12, 2002.

DIAS, R.; MELO, B. Proporção de material orgânico no substrato artificial para a produção de mudas de cafeeiro em tubetes. Ciência e agrotecnologia, Lavras, v. 33, n. 1, p. 144-152, maio/jun., 2009. 
DIAS, R.; MELO, B.; RUFINO, M. A.; SILVEIRA, D. L.; MORAIS, T. P.; SANTANA, D. G. Fontes e proporção de material orgânico para a produção de mudas de cafeeiro em tubetes. Ciência e agrotecnologia, Lavras, v. 33, n. 3, p. 758-764, maio/jun. 2009.

FARIAS JUNIOR, J. A.; CUNHA, M. C. L.; FARIAS, S. G. G.; MENEZES JUNIOR, J. C. Crescimento inicial de mudas de turco sob diferentes tipos de recipientes e níveis de luminosidade. Revista Brasileira de Ciências Agrárias, Recife, v.2, n.3, p.228-232, 2007.

FAVARIN, J. L.; FAVARIN JUNIOR, J. L.; REIS, A. R.; CAMARGO, F. T. Metodologia para estimar a estabilidade do conjunto muda x substrato de cafeeiro. Ciência Rural, Santa Maria, v.38, n.1, p.34-38, jan-fev, 2008.

FERREIRA, D. F. SISVAR - Sistema de análise de variância. Versão 5.3. Lavras: UFLA, 2010.

MARANA, J. P.; MIGLIORANZA, E.; FONSECA, E. P;. KAINUMA, R. H. Índices de qualidade e crescimento de mudas de café produzidas em tubetes. Ciência Rural, Santa Maria, v. 38, n. 1, p. 39-45, 2008.

MEDINA, C. L.; MACHADO, E. C.; SOUZA, R. P.; RIBEIRO, R. V.; SILVA, J. A. B. Photosynthesis response of citrus grown under reflective aluminized polypropylene shading nets. Scientia Horticulturae, Piracicaba, v. 96, n. 2, p. 115-125, 2002.

MENDONÇA, V.; ABREU, N. A. A.; SOUZA, H. A.; FERREIRA, E. A.; RAMOS, J. D. Diferentes níveis de composto orgânico na formulação de substrato para a produção de mudas de mamoeiro 'formosa'. Caatinga, Mossoró, v.20, n.1, p.49-53, 2007.

MENDONCA, V.; RAMOS, J. D.; RUFINI, J. C. M.; PIO, R.; CARRIJO, E. P.; GONTIJO, T. C. A. Diferentes substratos e ambientes na formação de mudas de maracujazeiro-amarelo. Revista Científica Rural, Bagé, v. 10, n. 2, p. 10-15, 2005.

PAIVA, L. C.; GUIMARÃES, R. J.; SOUZA, C. A. S. Influência de diferentes níveis de sombreamento sobre o crescimento de mudas de cafeeiro (Coffea arábica L.). Ciência e Agrotecnologia, Lavras, v. 27, n. 1, p. 134-140, 2003.

SANTOS, L. C. R.; COSTA, E.; LEAL, P. A. M.; NARDELLI, E. M. V.; SOUZA, G. S. A. de. Ambientes protegidos e substratos com doses de composto orgânico comercial e solo na formação de mudas de jatobazeiro em Aquidauana-MS. Engenharia Agrícola, Jaboticabal, v. 31, n. 2, p. 249259, 2011.

TATAGIBA, S. D.; PEZZOPANE, J. E. M.; REIS, E. F. Crescimento vegetativo de mudas de café arábica (Coffea arabica L.) submetidas a diferentes níveis de sombreamento. Coffee Science, Lavras, v. 5, n. 3, p. 251-261, set./dez. 2010. 